\title{
MARCIN GADOCHA
}

Uniwersytet Pedagogiczny im. Komisji Edukacji Narodowej w Krakowie

\section{JAN MICHAE KOSSOWICZ, DIARIUSZ PODRÓŻY PO EUROPIE (1682-1688) \\ OPRACOWAŁA, WSTĘPEM I KOMENTARZEM OPATRZYŁA ANNA MARKIEWICZ * \\ (2017), 748 P. ISBN 978-83-63580-80-3}

In recent years, a great deal of attention has been given to research on education-related trips in old Poland. Many scholars who study the history of the mentality, everyday life, culture, and education specifically, have unanimously agreed that the importance of such educational ventures abroad, in modern times, cannot be overestimated. The educational trip, peregrinatio academica, grand tour or any other form in between, was initially popular only with young noblemen and magnates ${ }^{1}$. However, by the second half of the seventeenth century, such a departure of young people to Italy or France had become linked, more or less permanently, to the system of national education. In modern times, studies abroad constituted not only the final stage of education, but also an important experience, decisive in the context of the student's future political or military endeavours. Foreign education also served as an affirmation of the high status of the students' parents, who

\footnotetext{
* A Diary of European Trav els (1682-1688), edited, annotated and introduced Anna Markiewicz

${ }^{1}$ See, among others: M. Kamecka, Do cudzych krajów. Edukacyjne podróże szlachty polskiej do Francji w epoce saskiej, (2012); A. Kucharski, Theatrum peregrinandi. Poznawcze aspekty staropolskich podróży w epoce późnego baroku, (2013); B. Popiołek, Podróże edukacyjne i poznawcze w źródłach czasów saskich, in: Polski Grand Tour w XVIII i początkach XIX wieku, ed. by A. Roćko, (2014), pp. 45-64.
} 
could afford the costly venture. A typical grand tour spanned several years. For instance, the trip of Jakub Sobieski, father of the future king, lasted six years (1607-1613), whereas his sons, Jan and Marek, spent two years abroad (1646-1648). Children of noble and magnate families typically left for Italy, France, the Netherlands (due to military engagements) or the Holy Roman Empire. Portugal, Spain or England were not nearly as popular, and Sweden had very few Polish visitors.

The Museum of King John III Sobieski Palace in Wilanów published A Diary of European Travels (1682-1688) by Jan Michał Kossowicz, edited and annotated by Anna Markiewicz, who also wrote the foreword to the work. Markiewicz, to whom I shall refer further as the editor in the present review, is a historian from Krakow, whose previous works include several high-quality books as well as source editions ${ }^{2}$. The work reviewed here describes an educational trip across Europe, completed by two sons of Stanisław Jabłonowski, a key figure in the Republic of the Two Nations: a Russian voivode, a Krakow kasztelan (town overseer) and hetman wielki koronny (great commander of the Kingdom). The two young men, Jan Stanisław and Aleksander Jan Jabłonowski, were abroad between 1682 and 1688. Their mother was Marianna née Kazanowska. For the purpose of the trip, two guardians were appointed, one of them was Jan Michał Kossowicz, an experienced and trusted Czernihow, and the other cześnik of Latyczów, Szymon Ignacy Gutowski. The work comprises of two main parts: an elaborate introduction (pp. 9-85) and the actual text of the travel diary (pp. 89-702), which contains two copies of travel instructions, written down by Stanisław Jan Jabłonowski for his sons (pp. 89-98 and pp. 152-159).

The introduction is further divided into sub-sections. The first part (pp. 9-16) is used by Anna Markiewicz to announce the theme of the work and

2 A. Markiewicz, Grand tour Aleksandra Jana i Jana Stanisława Jabłonowskich z lat osiemdziesiątych XVII wieku, in: Zeszyty naukowe Uniwersytetu Jagiellońskiego. Prace Historyczne, 132 (2005), pp. 57-69; eadem, Instrukcja wojewody ruskiego Jana Stanisława Jabłonowskiego dla wyruszającego w podróż zagraniczna bratanka Józefa Aleksandra Jabłonowskiego z 1728 roku, in: Studia Historyczne, 50 (2007), pp. 79-89; eadem, Peregrinationes Jablonovianae. Podróże edukacyjne w czasach Jana III Sobieskiego, (2011); Instrukcja hetmana Stanisława Jabłonowskiego do synów Jana Stanisława i Aleksandra Jana z 1682 r., in: Społeczeństwo a rodzina. Społeczeństwo Staropolskie. Seria Nowa, ed. by A. Karpiński, 3 (2011), pp.39-61; From Lviv to Paris. The Jabłonowski Brothers at the Jesuit College Louis-leGrand, 1684-86, in: Archivum Historicum Societatis Iesu, 85 (2016), pp. 187-219. See also other works by this author. 
share insightful comments on the nature of old travel ventures, especially the grand tour. In addition, she points out that Kossowicz's diary was written at a time of change of the general attitude towards educational trips. These ventures ceased to be viewed as merely "fashionable whims derided by authors of poems and strict moralists, and started to turn into an indispensable element of baroque education"3. Even so, such trips, completed with a large following, servants and other travellers, continued to serve as displays of the privileged status of affluent parents who could afford to send their sons to Europe ${ }^{4}$. Next, Markiewicz described some earlier publications devoted to educational trips by Polish, French and English scholars. This part of the book also provides the reader with some information on the history of the Diary itself. We find out that the work, considered lost, eventually resurfaced after many years.

Jan Michat Kossowicz as a tutor of Jan Stanisław and Aleksander Jan Jabłonowski (pp. 17-29) is the title of the following sub-section of the introduction, in which the Editor not only provides a detailed biography of the Diary author and his assistant, but also makes a preliminary reflection on the institution of mentor. She points out that, to this day, no scholar has undertaken research on the "peculiar, interesting and complex social group of the tutors accompanying young travellers" (p. 19). The biography section informs us that Kossowicz started his career in the military. In 1662, he was promoted by Samuel Leszczyński and granted the privilege of using the Wieniawa Coat of Arms. Most likely, it was due to his status as a soldier with distinguished service to his country that he became associated with the court of Hetman Stanisław Jan Jabłonowski. He first served in his armed unit and eventually became involved with his court. On Jabłonowski's orders, Kossowicz was given the position of Czernihow miecznik. Markiewicz also emphasizes that the guardian of the hetman's children had to be a person of a higher social status, and, most likely, this was the motive behind his swift promotion. Regarding this event, the editor quotes a Lviv Jesuit priest, Tomasz Perkowicz: "First the noblemen need a man titled with some honour for their own sake, so that even if he is a servant,

3 J. M. Kossowicz, Diariusz podróży po Europie (1682-1688), ed. by A. Markiewicz, (2017), p. 9.

${ }^{4}$ M. Chachaj, Orszak młodego magnata odbywającego podróż edukacyjna (wiek XVIXVIII), in: Patron i dwór. Magnateria Rzeczypospolitej w XVI-XVIII wieku, ed. by E. Dubas-Urwanowicz, J. Urwanowicz, (2006), p. 165 and next. 
he may be accepted. foreign people and this is why Most Revered Krakow master adorned the tutors with rule over land, even if only somewhere in partibus"s.

Markiewicz was right to point out that that the parents had to put great trust in the tutors. The choice of mentor was the most important matter to be attended to before the trip. The Editor quotes Stanisław Żółkiewski, also a hetman wielki koronny, who stated, "Your son will end up in the likeness of the mentor assigned to him"6. The guardian not only had to be honest, righteous, and trustworthy, but also well-travelled himself. He had to have had previous experience assisting with the travel ventures of other noblemen or magnates: he was expected to have already mastered the process of planning and coordinating such trips. Jan Michał Kosowicz's assistant was cześnik of Latyczów, Szymon Ignacy Gutowski, whose detailed biography Anna Markiewicz includes as well. The biography enables the reader to find out that, several years after the group's return from the trip, Gutowski was asked again by Hetman Jabłonowski to embark upon a new trip with his younger son, Stanisław Karol, in 1691. Gutowski must indeed have earned Jabłonowski's respect, for he was also given 10,000 Polish złoty for loyal service. We know that other magnates also entrusted their children to these two mentors. For instance, in 1695, Gutowski set out for Europe with the future king of Poland, Stanisław Bogusław Leszczyński.

The following sub-section of the introduction (pp. 29-72) is, above all, a more comprehensive summary of events recorded by the Diary, annotated with informative comments by the editor. The work of Kossowicz is a description of the lengthy journey of the two young magnates. While writing it down, the tutor did his best to keep track of the boys' educational progress as well as everyday life during their trip. Markiewicz points out that Kossowicz remained in the background of the stories he wrote down and rarely drew attention to his own difficulties experienced on this long journey. The grand tour in question began on September 12, 1682. The Diary was preceded. an elaborate instruction of the hetman addressed to

\footnotetext{
5 J. M. Kossowicz, Diariusz podróży po Europie, p. 23.

6 Pisma Stanisława Żółkiewskiego kanclerza koronnego i hetmana, ed. by A. Bielowski,
} (1861), p. 172. 
his sons. Stanisław Jan Jabłonowski exhorted his sons to "study with zeal, respect Sir Kosowicz and Sir Gutowski, listen to them, obey them, and hold on to God's grace, my love and blessing"7.

Anna Markiewicz also informs us that the youth usually prepared for their foreign ventures by attending Jesuit schools in Lviv. During the trip abroad, the boys had to enroll at the European Jesuit colleges indicated by the father in his letter. First, they attended the Mala Strana college in Prague, after a year, they moved to Clementinum, all while honing their German language skills in their spare time. Markiewicz recognizes the great value of the diary and the wealth of information it provides on the citizens of the Republic who were roaming Europe on educational trips in the eighties of the seventeenth century. While on the move, the hetman's sons often met with peers from other magnate or noble households, with whom they would travel together for some time or arrange meetings in towns on the way. Kossowski's meticulous notes described such events. While the group was sojourning in Prague, Szymon Gutowski delivered additional instructions from the hetman for the boys' prospective stay in Paris, along with special recommendations concerning a further itinerary covering several cities, among them Berlin, Dresden, Hamburg, Amsterdam and Louvain (Lovanium). The father also included study-related advice for their stay in Paris and some parental admonition.

Having arrived in the capital of France, the young travellers enrolled at the Jesuit college of Rue Saint-Jacques, College Louis-le-Grand. Anna Markiewicz writes that Kossowicz's detailed notes enable the reader to become familiar with the daily routines of the young boarders. During their stay in France, the young men went on a trip to England, where they visited places such as Canterbury, Rochester, London and Oxford. Following their two-year Jesuit instruction, the travellers remained in France in keeping with Hetman Jabłonowski’s instructions. They learnt various skills, such as fencing, horse-riding, dancing, and fortress-drawing. Markiewicz also points to the existence of another source, not so widely known, which documents the boys' stay in Paris. The W. Wernadski National Library in Kiev, Ukraine, preserves an anonymous manuscript featuring the Parisian

\footnotetext{
7 J. M. Kossowicz, Diariusz podróży po Europie, p. 90.
} 
notes of Aleksander Jan Jabłonowski. This source complements the Diary in a most valuable way and enables scholars to find out more about the actual subjects studied by the young men in Paris.

Next, the group made it to Madrid. Anna Markiewicz points out that this particular venture had not been foreseen in Hetman Stanisław Jan Jabłonowski’s instructions. According to her, no surviving correspondence confirms this change of plans. The group's journey to the Spanish capital took them through some famous sites of Southern France that filled the boys with awe. For instance, we know that the boys admired the fortifications of Bordeaux. The following destination of the European journey of the young magnates was Rome, where they were granted an audience with Pope Innocent XI and met with Queen Christina of Sweden. Next, they set out for Paris again. On the way, they visited Loreto, Ancona, Assisi, Florence, Venice and Turin. The itinerary was traced through the Alps, via Mont Cenis. According to Anna Markiewicz, at that time it was the most popular and typical transit trail of the Western Alps. In the French capital, Hetman Jabłonowski's sons resumed their education. Kossowicz's Diary also described some Poles encountered in Paris at that time. The travellers set out on their return journey on 6 October 1687, via Bavaria. In Regensburg, they changed their means of transport and opted for a barque. Next, the boys and the tutor made it to Vienna. The city of Pressburg was celebrating the coronation of Joseph I Habsburg as the king of Hungary, and the ceremony was attended by the young travellers. The last big city on their way back was Wrocław, where the boys had a number of social engagements. After six years, on 24 January 1688, the travellers finally returned to Lviv to the court of Hetman Stanisław Jabłonowski. The last sentence of the diary of Jan Michał Kossowicz was addressed to the older of the two boys, Jan Stanisław Jabłonowski.

The manuscript of Jan Michał Kossowicz's Diary is now preserved in Warsaw in the Royal Palace collections of Tomasz Niewodniczański. This short work, with the original signature of its author, is in good condition, and the handwriting suggests that Kossowicz was an experienced writer. The Diary was kept mainly in Polish, albeit with a number of Latin insertions, either words or entire phrases. The first page of the Diary bears the work's title Peregrination to foreign countries of the Most Noble Sirs Jan and Aleksander Jabłonowski, sons of Voivode of the Russia lands. This title is followed the proper text, written with very few corrections, occasionally 
featuring Kossowicz's additional comments scribbled above the primary version.

While elaborating her analysis, the editor of the Diary used a modified publishing instruction adapted to modern sources ${ }^{8}$. The abbreviations found in the work were deciphered skillfully, and all additional words inserted for the sake of clarity were placed in brackets. She also used the following symbol $<>$ to highlight the fragments added by Kossowicz to the body of the text. The illegible words were indicated with the following symbol $[\ldots]$. In sum, Markiewicz made every effort to stay close to the old Polish of the original. Even so, in keeping with editorial standards, she complemented the text with the missing diacritic symbols and preserved the characteristic modern forms and grammatical variations, such as the words barzo, abo, śrzodek, kawalier, ociec. She rendered the punctuation more modern, respecting contemporary orthography, even if, as she confessed, it was not always possible due to the "specific order and structure of the sentence". She seems to have done the right thing cleaning up the letters $i, j$ and $y$ to approximate contemporary orthography. She also preserved the orthography of numerals used by the Diary author. An undeniable asset of the reviewed edition is the work's preserved original layout along with the original paragraphs in most places. However, in order to make the text easier to read, Anna Markiewicz has added a few extra paragraphs. The consistent division of the text of the Diary into day entries reflects the rhythm of travelling characteristic of the old days. At the same time, it reflected the method the Diary author used in documenting the sites visited on the journey. The great effort of Anna Markiewicz put into the process of deciphering and identifying geographical sites, names, and last names written down by the Diary author is praiseworthy. As a side note, it needs to be acknowledged that isolated annotation errors constitute a common problem encountered by modern editors of old Polish sources. In the case of travel diaries, such errors can occur rather frequently and may be caused by haste, a lack of understanding or wrong information passed on to grand tour participants. For the sake of this edition, Anna Markiewicz has succeeded in deciphering and identifying the great majority of names of places, which is yet further proof of her fine editorial skills and familiarity

${ }^{8}$ K. Lepszy, Instrukcja wydawnicza dla źródeł historycznych od XVI do połowy XIX wieku, (1953). 
with both Polish and foreign scholarship in the field. She has also identified the individuals mentioned in the text on several occasions, and provided a more detailed description of the edifices admired by the travellers in various European cities. I wish to express my admiration for Markiewicz's painstaking work involved in the identification and description of individuals and towns seen by the travellers as well as the events hinted at by the source. She has also cited appropriate bibliographic references. In addition, to facilitate reading, Markiewicz has introduced a consistent system of factual and (even if just a few) textual footnotes, adding up to almost 3,600 . This impressive number gives us an accurate idea of the level of difficulty of the task she fulfilled with such remarkable success. Markiewicz also deserves praise for her professional translations of the relatively many foreign expressions found in the text, especially the Latin ones.

Anna Markiewicz enriched her edition with a great number of illustrations. Several dozen art reproductions, inserted in carefully-selected places, make it easier for the reader to gain familiarity with the world of the Diary. The drawings represent human silhouettes (Great Condeus, p. 349) encountered by the young travellers on their way, alongside drawings of edifices, such as Saint Paul's cathedral in London on page 297, map fragments, such as the map of the Kingdom of Naples on pages 480-482, fortress plans, the Coevordem fortress on page 220, and sketches from specific events, such as the coronation procession of James II on page 306. These visual elements provide the reader with props to imagine the actual persons or edifices from the Diary and place them in the context of the times. The edition also features the itinerary of Jan Michał Kossowicz, thanks to which the reader can track the 1682-1686 journey of the young magnates and their tutors. The Editor provided the names of towns in their contemporary form, with the original orthography of Kossowicz in parentheses, wherever the difference between the two was significant. In cases where Markiewicz did not manage to establish the contemporary geographical name of an old site, or the place no longer exists, she provided the original name of the town. The final pages of this extensive source edition feature person and place indexes, considered an indispensable element of critical editions of historical sources, and a must-have in the academic method used by editors of diaries from old Polish journeys ${ }^{9}$.

9 B. Rok, Uwagi nad problemem edytorstwa relacji podróżniczych czasów wczesnono- 
To sum up the above comments, I wish to recognize the high value of Anna Markiewicz's edition. Prepared to the highest editorial standards, it is a remarkably informative publication for any reader interested in following the young noblemen's European ventures. This edition deserves all the more attention, since late-seventeenth-century travel accounts of this type are rare. In my opinion, it is an important publication, as it presents new chapters of travel stories and makes them accessible to the public. Jan Michał Kossowicz offered a detailed description of the trip covering most of Europe, and meticulously documented the various stages of education of the two boys he supervised. Now, thanks to the Editor of his Diary, this description can serve historians who wish to reconstruct the everyday lives of the young travellers, their tutors, and third parties involved. The editor's in-depth knowledge of the subject matter is reflected in her insightful comments dissipating all doubt over unclear passages of the original text. Thanks to them, the reader is encouraged to make further inquiries. This is why the edition will appeal not only to individuals passionate about the old ways of travelling, but also to expert historians studying education, mentality, culture and art, should they wish to delve deeper into the matter.

In the light of the above, I strongly recommend that the publication of the Diary of European travels of Hetman Jabłonowski's sons, written by Jan Michał Kossowicz, be assessed very favourably, based both on the undeniable quality of the source edition and the fine academic method. In my capacity as reviewer, it is my duty to point out that the work is imperfect in one aspect; namely, the reader does not provide a comprehensive list of literature consulted on the subject or an index of images adorning the edition. The edition could also benefit from an index of objects, although I am aware that its compilation would require a lot of extra time and effort. Having stated this, I wish to reiterate that my criticism is not intended to diminish the high quality of the work as a whole.

The present edition is a great contribution to the tradition of publication of modern diaries of peregrinations, and, as such, can serve both as a model and a form of encouragement for scholars wishing to do research on other

wożytnych, in: Teoria i praktyka edycji nowożytnych źródeł w Polsce (XVI-XVIII w.), ed. by A. Perłakowski, (2011), pp. 159-167. 
old travel diaries. Last, but not least, the work of Anna Markiewicz demonstrates the imperative to peruse the archives, alongside other collections of various academic or cultural institutions, in the hope of finding unexpected gems, even if the object of the search is believed to have been lost, as in the case of the Diary of Jan Michał Kossowicz. 